\title{
Nilai Islami pada Proses Rekrutmen Karyawan di Universitas Muhammadiyah Malang
}

\author{
Sri Budi Cantika Yuli ${ }^{1}$, Nazaruddin Malik ${ }^{2}$
}

${ }^{1}$ Fakultas Ekonomi dan Bisnis Universitas Muhammadiyah Malang

${ }^{2}$ Fakultas Ekonomi dan Bisnis Universitas Muhammadiyah Malang

\begin{tabular}{|c|c|}
\hline Article & Abstract \\
\hline Information & $\begin{array}{l}\text { This study aimed at determining the understanding and implementation of Islamic } \\
\text { values in the recruitment process at University of Muhammadiyah Malang }\end{array}$ \\
\hline & $\begin{array}{l}\text { (UMM). This research applied qualitative method through a phenomenological approach } \\
\text { by scrutinizing informants' conscious experiences. The methods of data collection were }\end{array}$ \\
\hline & interviews, observation and documentation so that it can dig deeper into the \\
\hline & $\begin{array}{l}\text { implementation of Islamic values in the recruitment process at University of } \\
\text { Muhammadiyah Malang. The informants of this study were (1) University Leaders; (2) }\end{array}$ \\
\hline $\begin{array}{l}\text { Keywords: Islamic Values, } \\
\text { Recruitment Process, }\end{array}$ & $\begin{array}{l}\text { Employees. Further, the data collected were analyzed using three qualitative data } \\
\text { analysis techniques, namely: Data Reduction, Data Presentation, and Conclusion }\end{array}$ \\
\hline & Drawing. The results of this study indicated that the recruitment process at UMM: 1) in \\
\hline & $\begin{array}{l}\text { accordance with Islamic values sourced from the Qur'an and Hadith; 2) UMM leaders } \\
\text { have accomplished the mandate that was showed in selecting employees and establishing } \\
\text { the law fairly according to QS An Nisa (4) verse } 58 \text { and QS Al Maidah (5) verse 8; 3) } \\
\text { UMM Leaders appoint the most worthy and appropriate employees as in QS An Nisaa } \\
\text { (4) verse 59; 4) UMM leaders choose employees of the highest quality selectively in } \\
\text { accordance with the words of the Prophet Muhammad in HR. Baihaqi; 5) UMM } \\
\text { Leaders choose capable and trustworthy employees according to QS Al Anfaal (8) verse } \\
\text { 27. }\end{array}$ \\
\hline
\end{tabular}

\begin{abstract}
Abstrak
Penelitian ini bertujuan untuk mengetahui implementasi nilai islami pada proses rekrutmen di Universitas Muhammadiyah Malang (UMM). Penelitian ini menggunakan metode kualitatif. Penelitian ini menggunakan pendekatan fenomenologi, dengan meneliti pengalaman yang disadari oleh informan (conscious experience). Metode pengumpulan data melalui wawancara, observasi dan dokumentasi sehingga dapat menggali lebih dalam tentang implementasi nilai islami pada proses rekrutmen yang ada di Universitas Muhammadiyah Malang. Informan penelitian ini adalah (1) Pimpinan Universitas; (2) Karyawan. Teknik analisis data kualitatif dalam penelitian ini menggunakan 3 (tiga) analisis yaitu: Reduksi Data, Penyajian Data, dan Penarikan Kesimpulan. Hasil penelitian ini menyatakan bahwa Proses rekrutmen di UMM : 1) Sudah sesuai dengan nilai islami yang bersumber dari Al Qur'an dan Hadits; 2) Pimpinan UMM menunaikan amanah yang diwujudkan dalam memilih karyawan dan menetapkan hukum secara adil sesuai QS An Nisa (4) ayat 58 dan QS Al Maidah (5) ayat 8; 3) Mengangkat karyawan yang paling layak dan sesuai seperti dalam QS An Nisaa (4) ayat 59 ; 4) Memilih karyawan dengan kualitas terbaik secara selektif sesuai dengan sabda Rasulullah SAW dalam HR. Baihaqi; 5) Memilih karyawan yang mempunyai kapabilitas dan amanah sesuai QS Al Anfaal (8) Ayat 27
\end{abstract}


Praktik manajemen sumberdaya insani (MSDI) yang telah dilaksanakan oleh Nabi Muhammad SAW sejak awal dakwahnya dimulai dari pemilihan orang-orang yang diajak untuk masuk ke Islam. Selanjutnya Rasulullah menyiapkan sumberdaya insani yang memiliki loyalitas tinggi terhadap Islam, memegang amanah (tanggungjawab), dan memiliki komitmen lahir bathin (Fahmi, Siswanto, Farid, \& Abdurahman, 2013)

Perguruan tinggi sebagai sebuah organisasi sangat membutuhkan karyawan yang kreatif, memiliki kinerja tinggi, produktif, dan berkomitmen untuk mencapai dan mempertahankan keunggulan kompetitif. (Malik \& Naeem, 2011)

Peran karyawan bagi perguruan tinggi sangat penting. Peran para administrasi umum, tenaga administrasi akademik, pranata laboratorium, pustakawan, pengelola keuangan, satpam, dan arsiparis sangat menentukan proses pendidikan di perguruan tinggi. Dosen dan mahasiswa tidak bisa bekerja sendiri, mereka sangat membutuhkan pelayanan karyawan untuk kegiatan akademisnya. Karena itu, kualitas pelayanan karyawan sangat menentukan keberhasilan pelaksanaan Tri Dharma Perguruan Tinggi, yaitu pendidikan dan pengajaran, penelitian dan pengembangan dan pengabdian masyarakat.

Manajemen sumberdaya insani yang mengacu pada Al Qur'an dan Hadits meliputi merencanakan dan menarik sumberdaya insani yang berkualitas, mengembangkan sumberdaya insani agar berkualitas, menilai kinerja sumberdaya insani, memberikan motivasi dan memelihara sumberdaya insani yang berkualitas (Suyanto, 2008).

Menurut Raharjo (2011) manajemen sumberdaya insani yang unggul, cerdas dan berkarakter adalah seperti yang dicontohkan oleh Nabi Muhammad SAW. Unggul adalah keadaan dimana tiap insan memiliki kemampuan dan karakter yang baik serta dapat lebih baik daripada yang biasanya ada, dengan mampu memiliki kecerdasan intelektual (IQ), kecerdasan emosional (EQ), dan kecerdasan spiritual (SQ). Cerdas adalah insan sadar dan berusaha untuk mengetahui apa yang paling utama untuk diketahui dan dipahami dalam hidup agar dapat bahagia dan selamat di dunia dan di akhirat.

Sistem pengelolaan sumberdaya insani di Universitas Muhammadiyah Malang (UMM) mengacu pada Peraturan Universitas Muhammadiyah Malang No. 01 Tahun 2011 tentang PokokPokok Kepegawaian dan dilakukan secara terencana dan terbuka dalam pengertian mengakomodir pendapat dan pandangan dari lembaga, badan, fakultas, program studi dan juga mempertimbangkan kebijakan umum dari Pimpinan Pusat Muhammadiyah dalam hal ini Majelis Pendidikan Tinggi Pimpinan Pusat Muhammadiyah. Sistem pengelolaan sumberdaya insani mencakup (1). Perencanaan, (2). Seleksi/Perekrutan dan Pemberhentian, (3). Orientasi dan Penempatan Pegawai, (4). Pengembangan Karir Pegawai dan (5). Remunerasi, Retensi, Penghargaan dan Sanksi.

Untuk menjalankan proses tatakelola yang baik, selain dibantu melalui sistem informasi manajemen yang baik, UMM juga memiliki 680 orang karyawan yang meliputi tenaga kependidikan pustakawan, laboran/teknisi/programer, administrasi, dan lainnya: satpam/lapang.

Signifikansi penelitian ini terletak pada bagaimana nilai islami yang bersumber dari Al Qur'an dan Hadits diterapkan dalam proses rekrutmen karyawan di UMM.

\section{KAJIAN TEORITIK DAN HIPOTESIS}

\section{Nilai Islami}

Secara hakiki nilai Agama merupakan nilai yang memiliki dasar kebenaran yang paling kuat dibandingkan dengan nilai lainnya. Nilai ini bersumber dari kebenaran tertinggi yang datang dari Tuhan. Struktur mental manusia dan kebenaran mistik-transendental merupakan dua sisi unggul yang dimiliki oleh nilai Agama. Karena itu, nilai tertinggi yang harus dicapai adalah adanya keselarasan semua 
unsur kehidupan. Antara kehendak manusia dengan perintah Tuhan, antara ucapan dan tindakan, atau antara 'itiqad dan perbuatan (Fahmi et al., 2013)

Agama Islam sebagai Agama Allah yang disampaikan kepada Nabi Muhammad SAW memiliki kebenaran yang hakiki. Nilai dalam agama merupakan petunjuk, pedoman dan pendorong bagi manusia untuk memecahkan berbagai masalah hidup seperti ilmu agama, politik, ekonomi, sosial, budaya, dan militer, sehingga terbentuk pola motivasi, tujuan hidup dan perilaku manusia yang menuju kepada keridhaan Allah. Dalam Agama Islam terdapat beberapa pokok ajaran yang dapat menjamin bagi terwujudnya kehidupan manusia lahir batin, dunia akhirat. Oleh karena itu nilai keagamaan dalam Islam didasarkan pada pokok-pokok ajaran tersebut, yakni akidah, syariah dan akhlaq yang semuanya bersumber dari Al Qur'an.

\section{Manajemen Sumberdaya Insani (MSDI)}

Manajemen sumber daya insani dapat didefinisikan sebagai suatu proses perencanaan, pengorganisasian, pengarahan dan pengendalian sumber daya insani dalam rangka pencapaian tujuan organisasi (Hakim, 2009).

Sumber daya Insani (SDI) merupakan kekuatan terbesar dalam pengolahan seluruh sumber daya yang ada dimuka bumi, karena pada dasarnya seluruh ciptaan Allah yang ada dimuka bumi ini sengaja diciptakan oleh Allah untuk kemaslahatan umat manusia. Hal ini sangat jelas telah ditegaskan oleh Allah dalam Al-Quran surah Al-Jathiyah (45) ayat 13:

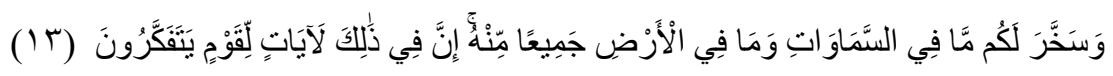

13. Dan Dia telab menundukkan untukmu apa yang di langit dan apa yang di bumi semuanya, (sebagai rahmat) daripada-Nya. Sesunggubnya pada yang demikian itu benar-benar terdapat tanda-tanda (kekuasaan Allah) bagi kaum yang berfikir.

Oleh karena itu sumber daya yang ada ini sebaiknya dikelola dengan benar karena itu merupakan amanah yang akan dimintai pertanggungjawabannya kelak. Untuk mendapatkan pengelolaan yang baik, ilmu sangatlah diperlukan untuk menopang pemberdayaan dan optimalisasi manfaat sunber daya yang ada. Di dalam surah Ar-Rahman ayat ke 33, Allah telah menganjurkan manusia untuk menuntut ilmu seluas-luasnya tanpa batas dalam rangka membuktikan kemahakuasaan Allah SWT. Ilmu pengetahuan yang dimaksud harus diarahkan kepada pengkajian terhadap Al Qur'an dan Hadits

Manajemen Sumber daya Insani (MSDI) merupakan semua sumber daya yang dimanfaatkan untuk ibadah kepada Allah, bukan untuk yang lainnya. Dengan adanya rasa menerima amanah dari Allah maka kemampuan yang dimiliki akan ditingkatkan dan dilakukan dalam rangka menjalankan amanah yang diemban. Sifat yang akan tercermin dari Sumber daya Insani yang baik ialah Siddiq, Amanah, Fatonah dan Tabligh. Keempat sifat ini adalah tolak ukur yang riil untuk mengukur keunggulan Sumber daya Insani.

Semua sifat dan keadaan yang ideal tersebut tentunya tidak akan ada dengan sendirinya melainkan harus dengan usaha yang sungguh-sungguh dan kesabaran yang luar biasa, sebagaimana firmanNya dalam surah Ar-Ra'd (13) ayat 11 :

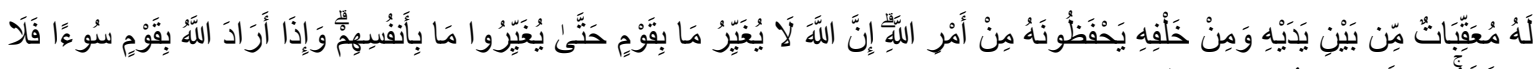

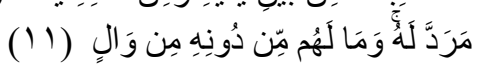


11. Bagi manusia ada malaikat-malaikat yang selalu mengikutinya bergiliran, di muka dan di belakangnya, mereka menjaganya atas perintah Allah. Sesunggubnya Allab tidak merubah keadaan sesuatu kaum sebingga mereka merubah keadaan yang ada pada diri mereka sendiri. Dan apabila Allah menghendaki keburukan terhadap sesuatu kaum, maka tak ada yang dapat menolaknya; dan sekali-kali tak ada pelindung bagi mereka selain Dia.

\section{Rekrutmen}

Syari'at Islam sebagai sistem hidup bagi manusia yang sempurna (syumuliyatul Islam) mengatur berbagai aspek kehidupan, termasuk menyangkut sumber daya manusianya. Profesionalisme dalam konsep Islam tentunya menyangkut kualitas akal (al-fikr), kualitas hati nurani (rubiyah) dan komitmen melaksanakan tugas (amaliyah).

Rekrutmen adalah proses pencarian calon karyawan, yang prosesnya meliputi serangkaian kegiatan yang dilakukan untuk memutuskan pelamar diterima atau tidak (Fahmi et al., 2013). Rekrutmen pegawai dibutuhkan dua syarat yaitu: "kuat dan amanah". Calon pegawai memiliki kekuatan meliputi kuat aqidah (quatul aqidah), cerdas (quatul fikr), wawasan jauh kedepan (tsaqofah), cerdas hatinuraninya (quatul rubiyab) dan bekerja professional (itqan).

Seorang pegawai memiliki amanahnya dalam melaksanakan tugas dan fungsi yang diberikan kepadanya. Faktor amanah sangat dibutuhkan sebagai kontribusi nyata mewujudkan pemerintahan yang bersih (good governance). Pegawai mampu menjalankan tugas yang diembankannya melalui kerja jujur, disiplin dan bertanggung jawab.

Pegawai yang professional atas bingkai iman perlu merenungkan penegasan Allah SWT dalam firman-Nya dalam QS Al Anfal ayat 27

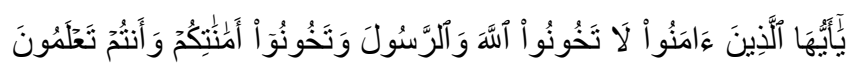

27. Hai orang-orang yang beriman, janganlah kamu mengkhianati Allah dan Rasul (Mubammad) dan (juga) janganlah kamu mengkhianati amanat-amanat yang dipercayakan kepadamu, sedang kamu mengetahui.

\section{Penelitian Terdahulu}

Menurut hasil penelitian Khan, Farooq, \& Hussain (2010) MSDM dalam perspektif Islam adalah Islam memberi petunjuk tentang nilai-nilai Islami dan diterapkan dalam kehidupan sehari-hari, Islam mengajarkan keadilan untuk memperlakukan karyawan setara dan tanpa memperdulikan tugas dan jabatan, setiap individu muslim harus mempraktekkan nilai-nilai Islami di tempat kerja, setiap individu muslim harus jujur, benar, berdedikasi tinggi, unggul, sukses dalam kehidupan dan pekerjaan dilakukan secara etika Islam.

Penelitian Alkahtani (2014) ini juga berusaha memahami dan menerapkan MSDI berdasar prinsip-prinsip Islami. Penelitian ini menggunakan pendekatan kualitatif berdasar tinjauan ekstensif dan menemukan hasil bahwa MSDI berdasar prinsip-prinsip Islami dapat memberi manfaat bagi organisasi dengan memfasilitasi karyawan yang sehat di lingkungan kerjanya, saling percaya, menghargai, konsultasi, berbagi pengetahuan, kreatif, dan inovasi antar karyawan. MSDI berdasar prinsip-prinsip Islam juga membantu penyelesaian konflik manajer dan pemilik (owner). Prinsip-prinsip Islami dalam MSDI meliputi : (1) Niat; (2) Taqwa; (3) Ikhsan; (4) Adil; (5) Amanah; (6) Siddiq; (7) Itqan; (8) Ikhlas; (9) Syura (musyawarah); (10) Sabar. 


\section{Kerangka Konseptual}

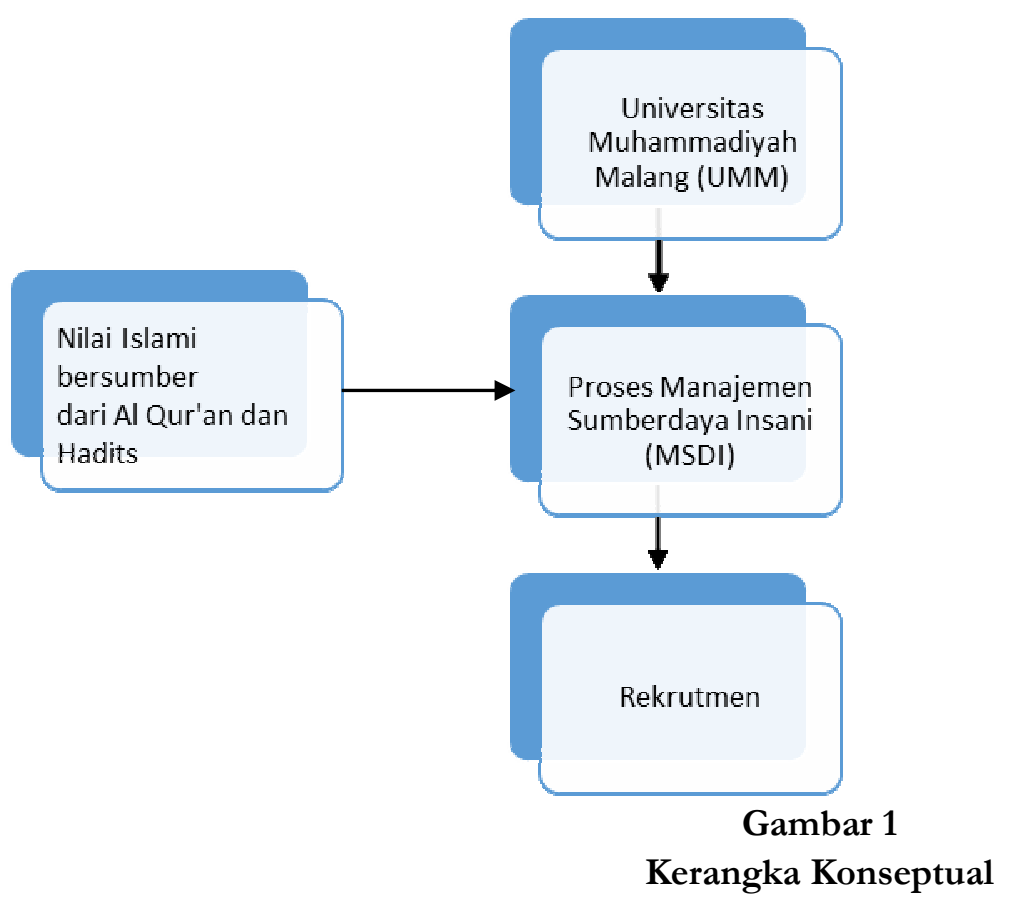

Pada kerangka konseptual dijelaskan bahwa dalam penelitian ini UMM sebagai sebuah Perguruan Tinggi mengelola organisasi berdasarkan nilai islami dalam implementasi proses manajemen sumberdaya insani (MSDM). Implementasi proses MSDM ditinjau dari aspek rekrutmen. Nilai islami dalam penelitian ini bersumber dari Firman Allah SWT di dalam Al Qur'an dan Hadits

\section{DATA DAN METODE}

\section{Jenis Penelitian}

Jenis penelitian ini deskriptif kualitatif yaitu penelitian tentang data yang dikumpulkan dan dinyatakan dalam bentuk kata-kata dan gambar, kata-kata disusun dalam kalimat, misalnya kalimat hasil wawancara antara peneliti dan informan. Alasan pemilihan metode kualitatif adalah dalam pendekatan kualitatif sering digunakan untuk melihat lebih dalam suatu fenomena sosial termasuk didalamnya kajian ilmu manajemen (Indrawan \& Yaniawati, 2016)

\section{Pendekatan Penelitian}

Penelitian ini menggunakan pendekatan fenomenologi, dengan meneliti pengalaman yang disadari oleh responden (conscious experience). Fenomenologi mengungkapkan bagaimana manusia mengalami kehidupannya di dunia. Penelitian kualitatif fenomenologi dapat dilakukan dengan tiga fase perenungan yaitu apoche (memberi tanda kurung), reduksi fenomenologi dan kemampuan berpikir dialektif (Wirawan, 2012)

\section{Teknik Analisis Data}

Teknik analisis data kualitatif dalam penelitian ini menggunakan 3 (tiga) analisis yaitu:

a. Reduksi Data 
Peneliti melakukan langkah-langkah merangkum, memilih hal-hal yang pokok, memfokuskan pada hal-hal yang penting, mencari tema dan pola, serta membuang yang tidak perlu. Proses reduksi data ini dilakukan oleh peneliti secara terus menerus saat melakukan penelitian untuk menghasilkan catatan-catatan inti dari data yang diperoleh dari hasil penggalian data.

b. Penyajian Data

Peneliti melakukan langkah penyajian data ini engan menyajikan sekumpulan informasi yang tersusun yang memberi kemungkinan adanya penarikan kesimpulan. Peneliti melakukan penyajian data ini dengan alasan data-data yang diperoleh selama proses penelitian kualitatif biasanya berbentuk naratif, sehingga memerlukan penyederhanaan tanpa mengurangi isinya.

Peneliti melakukan penyajian data untuk dapat melihat gambaran keseluruhan atau bagian-bagian tertentu dari gambaran keseluruhan. Pada tahap ini peneliti mengklasifikasikan dan menyajikan data sesuai dengan pokok permasalahan yang diawali dengan pengkodean pada setiap subpokok permasalahan

c. Penarikan Kesimpulan

Peneliti mengutarakan kesimpulan dari data-data yang telah diperoleh. Pada langkah penarikan kesimpulan ini peneliti mencari makna data yang dikumpulkan dengan mencari hubungan, persamaan, atau perbedaan.

Peneliti melakukan penarikan kesimpulan dengan jalan membandingkan kesesuaian pernyataan dari subyek penelitian dengan makna yang terkandung dengan konsep-konsep dasar dalam penelitian ini.

\section{ANALISIS DAN HASIL}

Berdasarkan hasil wawancara dengan pihak Pimpinan UMM, pelaksanaan rekrutmen karyawan dilakukan oleh tim yang ditetapkan dengan SK Rektor yang melibatkan lembaga sebagai satuan penjaminan mutu sumberdaya insani yaitu Biro Pengembangan Sumberdaya Manusia (BPSDM) bersama Biro Hukum dan Kepegawaian (BHK) dengan berpedoman pada Perencanaan dan Pengembangan Tenaga Kependidikan (P2TK). Pedoman dan dasar hukum pelaksanaan sistem seleksi karyawan di UMM ditetapkan dengan Keputusan Rektor terkait dengan sistem penilaian seleksi, pembentukan tim Seleksi, tim penilai microteaching, seleksi AIK, wawancara dan Psikotes.

Proses rekrutmen dan sistem penilaian yang telah dilakukan oleh UMM sesuai dengan prinsip keadilan seperti keteladanan Rasulullah, bahwa kewajiban pemimpin untuk menunaikan amanah diwujudkan dalam memilih karyawan dan menetapkan hukum secara adil, sebagaimana dinyatakan dalam QS An Nisa (4) ayat 58

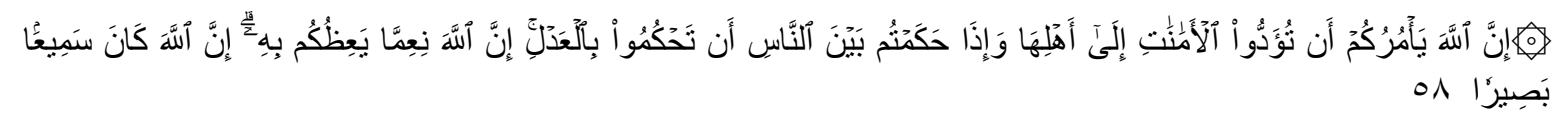

58. Sesungguhnya Allah menyuruh kamu menyampaikan amanat kepada yang berhak menerimanya, dan (menyuruh kamu) apabila menetapkan bukum di antara manusia supaya kamu menetapkan dengan adil. Sesunggubnya Allab memberi pengajaran yang sebaik-baiknya kepadamu. Sesunggubnya Allab adalah Maba Mendengar lagi Maha Melibat.

Hasil penelitian ini sejalan dengan penelitian Alkahtani (2014) bahwa penerapan prinsip-prinsip islami dalam proses MSDI salah satunya adalah sifat adil sebagaimana firman Allah SWT dalam QS Al Maidah (5) ayat 8 


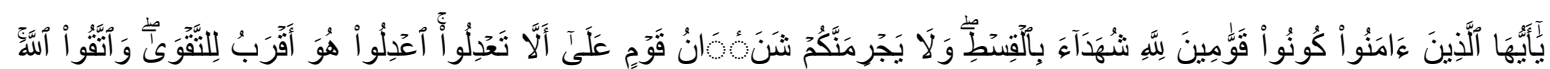

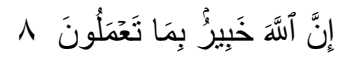

8. Hai orang-orang yang beriman hendaklah kamu jadi orang-orang yang selalu menegakean (kebenaran) karena Allah, menjadi saksi dengan adil. Dan janganlah sekali-kali kebencianmu terhadap sesuatu kaum, mendorong kamu untuk berlaku tidak adil. Berlaku adillah, karena adil itu lebih dekat kepada takwa. Dan bertakwalah kepada Allah, sesunggubnya Allah Maha Mengetahui apa yang kamu kerjakan.

Adil ini telah tercermin dari hasil wawancara dengan salah satu karyawan berikut ini (DAP) dengan masa kerja 7 tahun yang menyatakan bahwa :

"Saya masuk ke UMM pada tabun 2012, sebelum saya menjadi staf karyawan, saya merupakan tenaga parttimer di kantor Hubungan Luar Negeri selama 1 tabun. Setelah saya lulus dan diwisuda, saya diajukan untuk diangkat menjadi staf di kantor saya sekarang. Tes yang saya lalui sampai diterima yaitu meliputi tes wawancara, tes Bahasa Inggris, AIK, dan psikotest. Saya ditempatkan sesuai dengan kantor dimana saya diajukan untuk menjadi karyawan yaitu KHLN (Kantor Hubungan Luar Negeri)"

Proses rekrutmen karyawan di UMM juga mengindikasikan kewajiban pimpinan untuk memilih karyawan yang paling kompeten dan layak menempati jabatan tertentu untuk melaksanakan tugas secara efektif dan efisien, sebagaimana hasil wawancara dengan NWG yang telah bekerja selama 4 tahun berikut ini :

"Saya masuk di UMM tabun 2015. Saya mendapat panggilan untuk tes wawancara, psikotes, AIK dan tes praktik. pengoperasian computer. Saya ditempatkan di Direktorat Program Pascasarjana UMM. Pelatihan yang pernah saya ikuti itu penyusunan borang akreditasi prodi (Sistem SAPTO). Tanggung jawab pekerjaan saya pelayanan administrasi. Misalnya, pelayanan mahasiswa, penyusunan jadwal kuliah, penyusunan sajian mata kuliah, dan lainlain"

Proses rekrutmen yang dilakukan tersebut sesuai dengan keteladanan Rasulullah yaitu mengangkat individu yang paling layak dan sesuai sebagaimana dinyatakan dalam QS An Nisaa (4) ayat 59

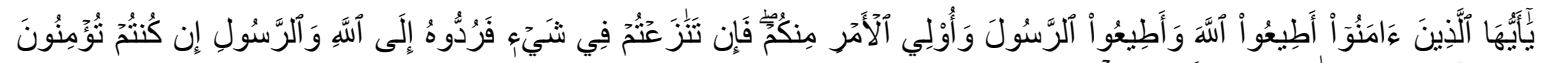

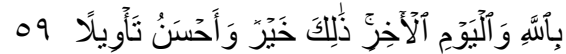

59. Hai orang-orang yang beriman, taatilah Allah dan taatilah Rasul (Nya), dan ulil amri di antara kamu. Kemudian jika kamu berlainan pendapat tentang sesuatu, maka kembalikanlab ia kepada Allab (AlQuran) dan Rasul (sunnabnya), jika kamu benar-benar beriman kepada Allah dan bari kemudian. Yang demikian itu lebih utama (bagimu) dan lebib baik akibatnya.

Proses rekrutmen karyawan di UMM juga mengindikasikan kewajiban pimpinan untuk memilih karyawan yang memiliki kualitas terbaik. Merekrut karyawan dengan kriteria yang sempurna, tidak mudah atau bahkan tidak ada. Sehingga apabila tidak ditemukan kriteria yang tanpa cela, maka tim penilai UMM harus memilih secara selektif seorang karyawan yang memiliki kualitas tertinggi dari sejumlah calon yang ada. 
Hasil wawancara dengan karyawan RIS yang telah bekerja selama 5 tahun di UMM menunjukkan bahwa proses rekrutmen karyawan di UMM memilih karyawan yang memiliki kualitas terbaik, sebagaimana yang dinyatakan berikut ini :

'Pada tahun 2014 saya bergabung dengan UMM. Saya membuat lamaran pada bulan Februari 2014 dengan melampirkan ijazah, transkrip, KTP, dan surat lamaran. Saya dipanggil tes pada bulan April 2014. Pada saat itu calon karyawan yang ikut barengan tes banyak bu, ada 20 an orang dan tidak semuanya diterima sebagai karyawan. Tim penilai membuat ranking. Kebetulan saya peringkat 1 jadi ya lolos sebagai karyawan UMM. Tes yang saya lakukan adalah wawancara, psikotes \& AIK (Al-Islam dan kemuhammadiyahan) dengan Bapak Dr. Abdul Haris, MA. Saya berusaha menjawab sesuai dengan yang saya ketahui dan kerjakan. Saya ditempatkan di Pascasarjana kampus 1 yang sekarang sudab berada di kampus 3. Tugas dan tanggungjawab saya menyusun jadwal üian dan pendistribusian Dosen Pengüi, merekap nilai masuk, entry nilai dan pelaporan wisuda. Terkadang juga membantu ujian dan kenangan. Sekarang jobdesk saya ditambah menjadi Tim Cek Plagiasi yang dinaungi LPPI (Lembaga Pengembangan Publikasi Ilmiab)”

Proses rekrutmen untuk memilih karyawan yang memiliki kualitas terbaik ini sesuai dengan sabda Rasulullah SAW:

"Barangsiapa mengangkat seseorang untuk mengurusi suatu perkara kaum muslimin, sementara ada orang yang lebih layak dan sesuai daripada orang-orang yang diangkatnya, maka sesunggubnya ia telah berkhianat kepada Allab dan Rasul-Nya" (HR. Baihaqi)

Proses rekrutmen karyawan di UMM juga mengindikasikan kewajiban pimpinan untuk memilih karyawan yang mempunyai kapabilitas dan amanah. Karyawan yang memiliki kapabilitas dan karakter amanah ini, sebagaimana hasil wawancara dengan LAF yang telah bekerja selama 7 tahun menyatakan bahwa :

"Saya mengajukan lamaran ke UMM ini Tahun 2012. Ada beberapa tahapan tes yang saya ikuti, tes tulis, Tes TAEP, menulis essay Bahasa Inggris dan wawancara, juga AIK (Al Islam Kemuhammadiyahan). Pertama diterima di UMM saya ditempatkan di IRO (International Relations Office) kemudian ditempatkean di Bidang Kesekretariatan Bidang I. Di IRO saya bertanggung jawab menjadi coordinator dosen asing, dan panitia berbagai macam acara internasional. Di kesekretariatan bidang I bertanggungjawab untuk membantu pekerjaan bidang I/Wakil Rektor I dan BAA (Biro Administrasi Akademik). Saya kerjakan apa yang menjadi tugas dan tanggungjawab saya, kadang saya juga diminta menjadi MC acara-acara kampus. Pernah sebagai pengawas tes TAEP sebagai penulis buku \& majalah, pernah mengikuti Pelatihan membuat aplikasi untuk pendaftaran masuk ke ESP Graduation, pelatihan pembuatan RPP dan kurikulum, pelatihan kepemimpinan. Semua saya ikuti dengan baik..."

Karyawan LAF yang melaksanakan pekerjaan dengan penuh tanggungjawab dan sesuai kemampuannya tersebut sesuai dengan Al Qur'an sebagaimana dalam Firman Allah QS Al Anfaal (8) Ayat 27 :

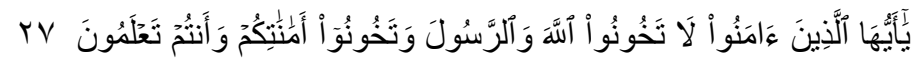

27. Hai orang-orang yang beriman, janganlah kamu mengkhianati Allah dan Rasul (Mubammad) dan (juga) janganlah kamu mengkhianati amanat-amanat yang dipercayakan kepadamu, sedang kamu mengetahui.

Hasil penelitian ini sejalan dengan penelitian Alkahtani (2014) yang menyatakan bahwa proses MSDI berdasar prinsip-prinsip Islami dapat memberi manfaat bagi organisasi dengan memfasilitasi 
karyawan yang sehat di lingkungan kerjanya, saling percaya, menghargai, konsultasi, berbagi pengetahuan, kreatif, dan inovasi antar karyawan. Prinsip-prinsip Islami dalam MSDI meliputi : (1) Niat; (2) Taqwa; (3) Ikhsan; (4) Adil; (5) Amanah; (6) Siddiq; (7) Itqan; (8) Ikhlas; (9) Syura (musyawarah); (10) Sabar.

Hasil penelitian ini juga sesuai dengan penelitian Khan et al. (2010) yang menyatakan bahwa setiap individu muslim harus mempraktekkan nilai-nilai Islami di tempat kerja, setiap individu muslim harus jujur, benar, berdedikasi tinggi, unggul, sukses dalam kehidupan dan pekerjaan dilakukan secara etika Islam.

\section{SIMPULAN}

Proses rekrutmen di UMM sudah sesuai dengan nilai islami yang bersumber dari Al Qur'an dan Hadits. Pimpinan UMM menunaikan amanah yang diwujudkan dalam memilih karyawan dan menetapkan hukum secara adil sesuai QS An Nisa (4) ayat 58 dan QS Al Maidah (5) ayat 8. Pimpinan UMM mengangkat karyawan yang paling layak dan sesuai seperti dalam QS An Nisaa (4) ayat 59. Pimpinan UMM memilih karyawan dengan kualitas terbaik secara selektif sesuai dengan sabda Rasulullah SAW dalam HR. Baihaqi. Pimpinan UMM memilih karyawan yang mempunyai kapabilitas dan amanah sesuai QS Al Anfaal (8) Ayat 27

\section{REFERENSI}

Cantika Yuli, S. B. (2005). Manajemen Sumber Daya Manusia. Malang: UMM Press.

Alkahtani, A. (2014). An Application of Islamic Principles in Building a Robust Human Resource Management System (In Islamic Countries). International Journal of Recent Advances in Organizational Behaviour and Decision Sciences, 1(3), 183-194.

Fahmi, A., Siswanto, A., Farid, F., \& Abdurahman. (2013). HRD Syariah: Teori dan Implementasi Manajemen Sumber Daya Manusia Berbasis Syariah. PT. Gramedia Pustaka Utama.

Hakim, A. (2009). Dinamika Manajemen Sumber Daya Manusia Dalam Organisasi (Pendekatan Konvensional dan Nilai-Nilai Islami). EF Press Digimedia Semarang.

Indrawan, R., \& Yaniawati, P. (2016). Metodologi Penelitian Kuantitatif, Kualitatif dan Campuran. (N. F. Atif, Ed.) (2nd ed.). Bandung: Penerbit Refika Aditama.

Khan, B., Farooq, A., \& Hussain, Z. (2010). Human resource management: an Islamic perspective. Asia-Pacific Journal of Business Administration, 2(1), 17-34. https://doi.org/10.1108/17574321011037558

Malik, M. E., \& Naeem, B. (2011). Impact of Perceived Organizational Justice on Organizational Commitment of Faculty : Empirical Evidence from Pakistan. Interdisciplinary Journal of Research in Business, 1(1991), 92-98.

Raharjo, M. M. (2011). Manajemen Sumber Daya Manusia yang Unggul, Cerdas dan Berkarakter Islam (1st ed.). Yogyakarta: Penerbit Gava Media.

Suyanto, M. (2008). Muhammad Business Strategy \& Etbics: Etika dan Strategi Bisnis Nabi Mubammad. Yogyakarta: Penerbit Andi.

Wirawan, I. B. (2012). Teori-Teori Sosial Dalam Tiga Paradigma (1st ed.). Jakarta: Prenadamedia Group.

Alkahtani, A. (2014). An Application of Islamic Principles in Building a Robust Human Resource Management System (In Islamic Countries). International Journal of Recent Advances in Organizational Behaviour and Decision Sciences, 1(3), 183-194. 
Fahmi, A., Siswanto, A., Farid, F., \& Abdurahman. (2013). HRD Syariah: Teori dan Implementasi Manajemen Sumber Daya Manusia Berbasis Syariah. PT. Gramedia Pustaka Utama.

Hakim, A. (2009). Dinamika Manajemen Sumber Daya Manusia Dalam Organisasi (Pendekatan Konvensional dan Nilai-Nilai Islami). EF Press Digimedia Semarang.

Indrawan, R., \& Yaniawati, P. (2016). Metodologi Penelitian Kuantitatif, Kualitatif dan Campuran. (N. F. Atif, Ed.) (2nd ed.). Bandung: Penerbit Refika Aditama.

Khan, B., Farooq, A., \& Hussain, Z. (2010). Human resource management: an Islamic perspective. Asia-Pacific Journal of Business Administration, 2(1), 17-34. https://doi.org/10.1108/17574321011037558

Malik, M. E., \& Naeem, B. (2011). Impact of Perceived Organizational Justice on Organizational Commitment of Faculty: Empirical Evidence from Pakistan. Interdisciplinary Journal of Research in Business, 1(1991), 92-98.

Raharjo, M. M. (2011). Manajemen Sumber Daya Manusia yang Ungoul, Cerdas dan Berkarakter Islam (1st ed.). Yogyakarta: Penerbit Gava Media.

Suyanto, M. (2008). Muhammad Business Strategy \& Etbics: Etika dan Strategi Bisnis Nabi Mubammad. Yogyakarta: Penerbit Andi.

Wirawan, I. B. (2012). Teori-Teori Sosial Dalam Tiga Paradigma (1st ed.). Jakarta: Prenadamedia Group. 